explicit judgments of risk. Clinicians should not assume that their patients and professional colleagues are likely to share their opinion whether treatment for hypertension is worth while.

I thank all the people who took part in this study, Brian Tom from the Centre for Applied Medical Statistics at Cambridge University for statistical advice, and Peter Brambleby and Malcolm Adams for their constructive comments.

NS is the sole author and acts as guarantor of the study.

Funding: NS was supported by a health services research fellowship from the NHS Executive Anglia and Oxford Research and Development Directorate.

Competing interests: None declared.
1 Reed WW, Herbers JE, Noel GL. Cholesterol-lowering therapy: what patients expect in return.J Gen Intern Med 1993;8:591-6.

2 Friedmann PD, Brett AS, Mayo-Smith MF. Differences in generalists' and cardiologists' perceptions of cardiovascular risk and the outcomes of preventive therapy in cardiovascular disease. Ann Intern Med 1996;124: 414-21.

3 Mulrow C, Lau J, Cornell J, Brand M. Antihypertensive drug therapy in the elderly. Cochrane Collaboration. Cochrane Library, Issue 1; Oxford: Update Software, 1998.

4 Guevffier F, Froment A, Gouton M. New meta-analysis of treatment trials of hypertension: improving the estimate of therapeutic benefit. J Hum Hypertens 1996;10:1-8.

5 Ramsay LE, Williams B, Johnston GD, MacGregor GA, Poston L, Potter $\mathrm{JF}$, et al. British Hypertension Society guidelines for hypertension management 1999: summary. BMJ 1999;319:630-5.

(Accepted 13 December 1999)

\title{
Aggression and violent behaviour in general practice: population based survey in the north of England
}

\author{
Graham J Ness, Allan House, Andrew R Ness
}

Three studies, the last one eight years ago, have suggested that general practitioners in the United Kingdom are frequently subjected to verbal abuse, with an estimated annual frequency of such incidents of between $25 \%$ and $59 \% .{ }^{1-3}$ In one of these studies $5 \%$ of general practitioners reported having been threatened with a weapon in the preceding year ${ }^{3}$; annual rates of physical injury ranged from $1 \%$ to $11 \% .^{1-3}$ These three studies, and subsequent discussion, raised concern that aggression towards general practitioners was becoming more common. To estimate accurately the current frequency of such incidents we undertook a survey of general practitioners working in a health authority in the north of England.

\section{Subjects, methods, and results}

During May to September 1997 we sent a brief questionnaire to all 419 general practice principals in the area administered by Leeds Health Authority. Principals were asked to recall their experiences of aggression directed at themselves at work over the previous year in four categories: verbal abuse, specific threats, physical action without injury, and serious incidents (including threats with a weapon or attacks leading to physical injury). We obtained the Jarman index ${ }^{4}$ for each electoral ward. This showed the percentage of patients attracting deprivation payments on that practice's list. The score was used to classify practices as high or low deprivation according to whether the percentage was above or below the median for the sample.

Completed questionnaires were returned by 380 (91\%) principals (244 men, 136 women). The table shows the numbers of respondents who experienced any of the four categories of aggression and the incidence of aggression by deprivation. A higher proportion of women than men reported experiencing verbal abuse, but a higher proportion of men than women reported physical contact abuse or a serious incident. A higher proportion of doctors in the high deprivation practices reported aggression than doctors in the low deprivation practices.

One doctor was involved in an incident that resulted in minor physical injury, and in five incidents doctors were threatened with a weapon. Two of these incidents involved patients described as psychotic at the time of the attack; a further three involved a patient with an alcohol or substance misuse problem.
School of Health and Related Research, University of Sheffield, Sheffield S1 4DA Graham J Ness clinical lecturer in forensic psychiatry Academic Unit of Psychiatry and Behavioural Sciences, Leeds LS2 9LT

Allan House professor in liaison psychiatry continued over

BMJ 2000;320:1447-8

Reported aggression at work towards 380 general practitioners covering the population of Leeds Health Authority during 1997

\begin{tabular}{|c|c|c|c|c|c|c|c|c|}
\hline \multirow[b]{2}{*}{ Respondents } & \multicolumn{2}{|c|}{ Verbal abuse } & \multicolumn{2}{|c|}{ Specific threats } & \multicolumn{2}{|c|}{ Physical action } & \multicolumn{2}{|c|}{ Serious incidents } \\
\hline & $\begin{array}{l}\text { No of } \\
\text { respondents }\end{array}$ & $\begin{array}{c}\% \text { of respondents } \\
(95 \% \mathrm{CI}))\end{array}$ & $\begin{array}{c}\text { No of } \\
\text { respondents }\end{array}$ & $\begin{array}{l}\% \text { of respondents } \\
(95 \% \mathrm{Cl})\end{array}$ & $\begin{array}{c}\text { No of } \\
\text { respondents }\end{array}$ & $\begin{array}{l}\% \text { of respondents } \\
(95 \% \mathrm{Cl})\end{array}$ & $\begin{array}{c}\text { No of } \\
\text { respondents }\end{array}$ & $\begin{array}{l}\% \text { of respondents } \\
(95 \% \mathrm{Cl})\end{array}$ \\
\hline All & 205 & 54 (49 to 59$)$ & 108 & 28 (24 to 33 ) & 24 & $6(4$ to 9$)$ & 6 & $1.6(0.7$ to 3.4$)$ \\
\hline Male $(n=244)$ & 121 & 50 (43 to 56$)$ & 63 & 26 (21 to 32 ) & 17 & 7 (4 to 11$)$ & 5 & $2.0(0.8$ to 4.7$)$ \\
\hline Female $(n=136)$ & 84 & 62 (53 to 70$)$ & 45 & 33 (26 to 41$)$ & 7 & $5(3$ to 10$)$ & 1 & $0.7(0.1$ to 4.1$)$ \\
\hline Relative risk (male $v$ female) & & $1.3(1.0 \text { to } 1.5)^{\star}$ & & $1.3(0.9$ to 1.8$)$ & & $0.7(0.3$ to 1.7$)$ & & 0.4 (0.04 to 3.04$)$ \\
\hline $\begin{array}{l}\text { High deprivation practices } \\
(\mathrm{n}=181)\end{array}$ & 119 & 66 (59 to 72$)$ & 71 & 39 (32 to 47$)$ & 18 & 10 (6 to 15$)$ & 5 & 2.8 (1.2 to 6.3$)$ \\
\hline $\begin{array}{l}\text { Low deprivation practices } \\
(\mathrm{n}=199)\end{array}$ & 86 & 43 (37 to 50$)$ & 37 & 19 (14 to 25$)$ & 6 & 3 (1 to 6$)$ & 1 & 0.5 (0.09 to 2.8$)$ \\
\hline $\begin{array}{l}\text { Relative risk (more } \\
\text { deprived/less deprived) }\end{array}$ & & $1.5(1.3 \text { to } 1.8)^{\star *}$ & & $2.1(1.5 \text { to } 3.0)^{\star *}$ & & $3.3(1.3 \text { to } 8.1)^{*}$ & & $5.5(0.7$ to 46.6$)$ \\
\hline
\end{tabular}

${ }^{\star} \mathrm{P}<0.05$, ${ }^{*} \mathrm{P}<0.001$ (calculated by using $\chi^{2}$ test or Fisher's exact test).

tCalculated by using the technique described by Wilson. 
Department of Social Medicine,

University of

Bristol, Canynge

Hall, Bristol

BS8 2PR

Andrew R Ness

senior lecturer in

epidemiology

Correspondence to: G J Ness g.j.ness@sheffield. ac.uk

\section{Comment}

In our cross sectional study, over half of the 380 respondents reported experiencing verbal abuse in the preceding year at work, but only five reported being threatened with a weapon and only one reported physical injury. General practitioners serving deprived populations were more likely to report verbal abuse and more serious incidents, and our results show that the risk of more serious episodes in deprived areas might be disproportionately high.

Caution is needed in interpreting the results because of possible bias from retrospective reporting and from the lack of a definition of verbal violence in the questionnaire. None the less, the rate of verbal abuse in our study was similar to that reported in the largest previous study carried out by Hobbs in 1991²; Hobbs's study, however, reported an annual rate of physical injury of 3.8\% compared with $0.3 \%(1 / 380)$ in our survey.

Several factors might explain the lower rates of serious incidents in our study. High rates of serious incidents observed in previous studies may have been overestimates if those who had experienced the serious incidents were more likely to be among the proportion who returned questionnaires (in Hobbs's main study, this proportion was only $40 \%{ }^{2}$ ). Previous investigators might have surveyed general practitioners covering areas where violent behaviour towards doctors is more common. Finally, a genuine reduction might have occurred.
Future studies should examine the psychological effect of frequent verbal abuse on primary care workers. In addition, a prospective inquiry should be set up to identify and describe serious incidents in more detail.

GJN undertook this study for the Leeds masters in medical sciences in clinical psychiatry. We thank the general practitioners who completed the questionnaire and staff at Leeds Health Authority who assisted with this survey.

Contributors: GJN had the original idea for the study, carried out the fieldwork and prepared the manuscript for publication. AH advised on the design and execution of the study and helped to prepare the paper for publication. ARN carried out the analysis and helped to prepare the paper for publication. GJN is the guarantor for the paper.

Funding: Partial funding from the Max Hamilton Memorial, a charity that specifically funds research for the Leeds psychiatry masters.

Competing interests: None declared.

1 D'Urso P, Hobbs R. Aggression and the general practitioner. $B M J$ 1989;298:97-8.

2 Hobbs FDR. Violence in general practice: a survey of general practitioners' views. BMJ 1991;302:329-32.

3 Health Services Advisory Committee. Violence to staff in the health services. HMSO: London, 1987.

4 Jarman B. Identification of underprivileged areas. BMJ 1983;286:1705-9 5 Wilson EB. Probable inference, the law of succession, and statistical inference. J Am Stat Assoc 1927;22:209-12.

(Accepted 21 January 2000)

\section{Books of life, death-and what comes in between}

I registered a death recently.

I had to make an appointment, which seemed a rather formal business. The registrar sat behind a computer. She stood up and we introduced ourselves. It would take about half an hour, she explained.

It was a surprisingly dignified occasion. She unfolded the death certificate from its familiar brown envelope, laid it out on her desk, and studied it carefully. I thought of the hundreds of certificates that I have quickly filled in and torn from that orange book in my desk drawer. We steadily worked our way through a series of questions on her computer. When that was done, she took out a fountain pen and recorded the details in her register, in black ink. Then she asked me how many copies I wanted.

I had assumed that they were certificates in their own right, but she explained patiently that these were but copies, showing me the wording: "Certified copy of an entry." The register was the reality, and the certificates - despite all the computer entries-no more than copies of that entry in the book. They were duly printed out on the official paper, which was watermarked and crown headed. My little ceremony was over and I went back to the surgery, thinking about the importance attributed to the handwritten record.

Enjoyable and distinctive as they are, I have no sentimentality about our old notes. We often talked about our policy of entering everything into the computer while also maintaining (more or less) the Lloyd George notes. Anyway, as a result in our practice the written record is no longer fully reliable. But curiously, it's as if some of us don't yet feel able to put our complete trust in the computer.

This is interesting, as we've just jettisoned what was thought to be an essential part of the practice-the appointment book. This recorded what's happened in the past and who'd seen whom. It also predicted the future, foretelling who was going to see whom. A handwritten page, open whenever anyone was consulting. And when the surgery was closed, so it would be too. Hardly surprising then that it wasn't just receptionists who were anxious when the large, black backed book went.

"Going paperless" is, of course, far more complicated than the simple phrase suggests. Still, it represents an ideal to work towards for many of us in general practice. But my visit to the registrar had me thinking about the significance of the handwritten word. Perhaps we need to be reminded of one crucial part of our job-that of transcriber, of recorder, as the keeper of the story. In the book A Fortunate Man by John Berger the GP "does more than treat them when they are ill; he is the objective witness of their lives ... the clerk of their records."

This is an important part of our work, by which the subjective experience of our patients is translated into objective fact. It is a duty which is unspoken but expected.

No doubt, all this can be achieved through modern information technology. And there's no need for us to do this any longer in black ink in a book.

Still, it is interesting that words on paper are referred to as hard copy. My visit to the registrar leaves me wondering about a continuing, deeprooted need for the reality of the handwritten word on the page of a book. At least, for the important things.

\section{Richard Westcott general practitioner, South Molton, Devon}

We welcome articles of up to 600 words on topics such as A memorable patient, A paper that changed my practice, My most unfortunate mistake, or any other piece conveying instruction, pathos, or humour. If possible the article should be supplied on a disk. Permission is needed from the patient or a relative if an identifiable patient is referred to. We also welcome contributions for "Endpieces," consisting of quotations of up to 80 words (but most are considerably shorter) from any source, ancient or modern, which have appealed to the reader. 